Agrovoc descriptors: rosemary, rosmarinus officinalis, antimicrobial properties, listeria monocytogenes, resistance to injurious factors, biological differences, plant extracts, concentrating, essential oils, foods, food additives, contamination, food processing, preservation

Agris category code: Q03, Q05

\title{
Antimicrobial activity of rosemary extracts (Rosmarinus officinalis L.) against different species of Listeria
}

\author{
Tanja ROŽMAN ${ }^{1}$, Barbara JERŠEK ${ }^{2}$
}

Received September 11, 2008; accepted April 2, 2009.

Delo je prispelo 11. septembra 2008; sprejeto 2. aprila 2009.

\section{ABSTRACT}

Reduction or elimination of chemically synthesized additives from foods is a current demand in food industry. A new approach to prevent the proliferation of microorganisms or protect food from oxidation is the use of essential oils or plant extracts as natural additives in foods. We have studied antimicrobial activity of rosemary extracts (Rosmarinus officinalis L.) against different species of Listeria and against different strains of $L$. monocytogenes. We used two extracts of rosemary, VivOX 20 and VivOX 40 (Vitiva d.d., Slovenia) containing different levels of carnosic acid. We wanted to proof an antimicrobial activity of selected rosemary extracts with two most commonly used methods: disc diffusion method and broth dilution method. With the disc diffusion method we have obtained the inhibition zone and at the lowest concentrations, where no visible bacterial growth was recorded, were assumed as minimal inhibitory concentration values (MIC). We determined MIC values in the ranges from $625 \mu \mathrm{g}$ extract $/ \mathrm{ml} \mathrm{EtOH}$ to $5000 \mu \mathrm{g}$ extract $/ \mathrm{ml} \mathrm{EtOH}$ for VivOX 20 and from $312.5 \mu \mathrm{g}$ extract $/ \mathrm{ml} \mathrm{EtOH}$ do $2500 \mu \mathrm{g}$ extract $/ \mathrm{ml} \mathrm{EtOH}$ for VivOX 40 in the medium. We have established that the resistance of Listeria species against rosemary extracts depends on: selected extract, selected concentration, various species and strain of Listeria. With broth dilution method we have determined minimal bactericidal concentration (MBC), as the concentration giving $0.1 \%$ bacterial survival. With this method we have tested two strains of $L$. monocytogenes and in determinate $\mathrm{MBC}$ values in the range from $15.63 \mu \mathrm{g} / \mathrm{ml} \mathrm{TSB}$ to $98.5 \mu \mathrm{g} / \mathrm{ml}$ TSB for both tested extracts. Results have confirmed our assumption that resistance of Listeria against rosemary extracts depended on the selected strain.

Keywords: pathogens, Listeria, Listeria monocytogenes, plant extracts, rosemary, antimicrobial activity, carnosic acid, minimal inhibitory concentration, minimal bactericidal concentration

\section{IZVLEČEK}

Zahteve potrošnikov po celem svetu so zmanjšati oz. izločiti kemično sintetizirane konzervanse iz živil. Novejše metode preprečevanja mikrobne kontaminacije in oksidacije uporabljajo eterična olja ali rastlinske ekstrakte kot naravne konzervanse. Proučevali smo protimikrobno delovanje ekstraktov rožmarina (Rosmarinus officinalis L.) na različne vrste bakterij rodu Listeria in seve bakterij L. monocytogenes. Uporabili smo dva različna komercialno pripravljena ekstrakta rožmarina, VivOX 20 in VivOX 40 (Vitiva d.d., Slovenija), ki sta vsebovala različno koncentracijo karnozolne kisline. Protimikrobni učinek izbranih ekstraktov smo želeli dokazati z dvema najpogosteje uporabljenima metodama: metoda difuzije $\mathrm{v}$ trdnem gojišču in metoda razredčevanja $\mathrm{v}$ tekočem gojišču. Pri metodi difuzije v trdnem gojišču smo po inkubaciji odčitali nastale inhibicijske cone, s katerimi smo določili minimalne inhibitorne koncentracije (MIC), kot tiste koncentracije, pri katerih ni bilo vidne rasti bakterij na gojišču. Vrednosti MIC smo določili v območju med $625 \mu \mathrm{g}$ ekstrakta/ml EtOH do $5000 \mu \mathrm{g}$ ekstrakta/ml EtOH za ekstrakt VivOX 20 in med $312,5 \mu \mathrm{g}$ ekstrakta/ml EtOH do $2500 \mu \mathrm{g}$ ekstrakta/ml EtOH za ekstrakt VivOX 40. Ugotovili smo, da je odpornost listerij proti ekstraktoma rožmarina odvisna od izbranega ekstrakta, izbrane koncentracije ter vrste in seva listerij. Z metodo razredčevanja $\mathrm{v}$ tekočem gojišču smo določali minimalne baktericidne koncentracije (MBC), kot tiste koncentracije, pri katerih preživi $0,1 \%$ testnih bakterij. Uporabili smo dva različna seva bakterij vrste $L$. monocytogenes in vrednosti MBC v večini poskusov določili med $15,63 \mu \mathrm{g} / \mathrm{ml}$ gojišča TSB in $98,5 \mu \mathrm{g} / \mathrm{ml}$ gojišča za oba uporabljena ekstrakta. Rezultati so ponovno potrdili našo domnevo, da je odpornost listerij proti ekstraktoma rožmarina odvisna od seva.

Ključne besede: patogeni mikroorganizmi, Listeria, Listeria monocytogenes, rastlinski ekstrakti, rožmarin, protimikrobno delovanje, karnozolna kislina, minimalna inhibitorna koncentracija, minimalna baktericidna koncentracija

\footnotetext{
${ }^{1}$ Univ. v Ljubljani, Biotehniška fakult., Odd. za živilstvo, Jamnikarjeva 101, 1111 Ljubljana, Slovenija

${ }^{2}$ Univ. v Ljubljani, Biotehniška fakult., Odd. za živilstvo, Jamnikarjeva 101, 1111 Ljubljana, Slovenija
} 


\section{INTRODUCTION}

Food market trends are changing. Consumers demand more high-quality foods with fresh like attributes; consequently less extreme treatments and/or additives are being required. Lipid oxidation and bacterial contamination are the main factors that determine food quality loss and shelf-life reduction. Therefore, delaying lipid oxidation and preventing bacterial crosscontamination are highly relevant to food processors. Oxidative processes and bacterial contamination, in turn, contribute to the deterioration in flavour, texture and color of food products (Fernandez-Lopez et al., 2004).

Growth of microorganisms in food may cause spoilage or foodborne disease (Del Campo et al., 2000). Synthetic additives have been widely used. The trend is to decrease their use because of the growing concern among consumers about such chemical additives. Consequently, search for natural additives, especially of plant origin, has notably increased in recent years. Therefore, the development and application of natural products with both antioxidants and antibacterial activities especially in meat products may be necessary and useful to prolong their storage shelf life and potential for preventing food diseases (Fernandez-Lopez et al., 2004).

Rosemary (Rosmarinus officinalis L.) originally grows in southern Europe. Its herb and oil are commonly used as spice and flavoring agents in food processing for its desirable flavor, high antioxidant activity and lately as antimicrobial agent (Lo et al., 2002; Ouattara et al., 1997). Moreno et al. (2006) reported that rosemary plants are rich sources of phenolic compounds with high antimicrobial activity against both Gram-positive and Gram-negative bacteria. High percent of the antimicrobial activity they attributed to carnosic acid and carnosol. It is clear that rosemary extracts have bioactive properties, but their antimicrobial activities have not been deeply characterized. Antimicrobial activities of plant essential oils have been known for centuries, but their strong flavor limited their use in food (Del Campo et al., 2000).

Although the antimicrobial properties of essential oils and their components have been reviewed in the past (Shelef, 1983; Nychas, 1995), the mechanism of action has not been studied in great detail. Considering the large number of different groups of chemical compounds present in essential oils, it is most likely that their antibacterial activity is not attributable to one specific mechanism but that there are several targets in the cell (Burt, 2004).

Listeria is aerobic, microaerophilic, facultatively anaerobic, catalase positive and oxidase negative, small, regular Gram-positive rod with rounded ends (Rocourt and Buchrieser, 2007) and is frequently present in human environment (Fenlon, 1999). Only two of the six species in this genus are currently recognized to be pathogenic: L. monocytogenes and L. ivanovii. They cause listeriosis, an opportunistic infection of humans and animals involving severe clinical manifestations such as meningoencephalitis, abortion and septicemia (Vazquez - Boland et al., 2001). Human cases of $L$. ivanovii infection are rare (Gandhi and Chikindas, 2007; Zhang et al., 2007), being pathogenic mostly for ruminants (Vazquez - Boland et al., 2001), whereas $L$. monocytogenes has been recognized as a human foodborne pathogen since 1929 (Painter and Slutsker, 2007; Zhang et al., 2007).

Listeriosis is foodborne illness and therefore the rapid and accurate detection of $L$. monocytogenes is important for food safety assurance. L. monocytogenes can be found in a wide variety of raw and processed foods. Milk and dairy products, various meats and meat products such as beef, pork, fermented sausages, fresh produce such as radishes, cabbage, seafood and fish products have all been associated with Listeria contamination (Gandhi and Chikindas, 2007). The temperature range that permits growth of $L$. monocytogenes is of particular interest to food processors because this pathogen is a psychotropic bacterium. L. monocytogenes was reported to grow at temperatures between -1.5 and $45^{\circ} \mathrm{C}$ (Lado and Yousef, 2007), between $\mathrm{pH} 4.5$ and $\mathrm{pH} 9.2$, optimally at $\mathrm{pH} 7$. It can grow in $10 \%(\mathrm{w} / \mathrm{v}) \mathrm{NaCl}$ and survive at higher concentrations. Survival at low $\mathrm{pH}$ and high salt concentration depends strongly on temperature. Listeria is one of the few foodborne pathogens that can grow at $\mathrm{a}_{\mathrm{w}}$ below 0.93 (Rocourt and Buchrieser, 2007).

The aim of our work was to investigate antilisterial activity of rosemary extracts VivOX 20 and VivOX 40 in concentrations that can be used as natural additives in foods. 


\section{MATERIALS AND METHODS}

\subsection{Bacterial cultures and preparation of rosemary extracts}

We tested antibacterial activity of rosemary extracts against 4 different species of Listeria. As L. monocytogenes is well known foodborne pathogen, we decided to use 8 different strains. All used cultures are listed in table 1.

Cultures were grown in BHI broth (Brain Heart Infusion broth, Merck, 1.10493, Germany) at $37{ }^{\circ} \mathrm{C}$ for $20-24 \mathrm{~h}$ with shaking. Suspension from BHI was then diluted in sterile BP (Butterfield's phosphate buffered dilution water $(\mathrm{pH} 7.2 \pm$ 0.1)) till final concentration $10^{7} \mathrm{CFU} / \mathrm{ml}$. Viable counts were obtained by plating 10 -fold dilutions made in sterile BP and plated onto TSA (Tryptone Soy Agar, Oxoid, CM0131, England) in duplicates. After incubating plates for $24-48 \mathrm{~h}$ at $37^{\circ} \mathrm{C}$ the number of bacteria was calculated as colony forming units.

Table 1: Listeria strains used for testing antibacterial activity of rosemary extracts

\begin{tabular}{l|l}
\hline Listeria strain designation & Origin, serotype \\
\hline Listeria grayi ŽM66 & IHG reference strain, / \\
Listeria innocua ŽM68 & Isolated from sausage, / \\
Listeria ivanovii ŽM65 & IHG reference strain, 5 \\
Listeria monocytogenes ŽM51 & IHG reference strain, 1/2a \\
Listeria monocytogenes ŽM52 & IHG reference strain, 1/2b \\
Listeria monocytogenes ŽM53 & IHG reference strain, 1/2c \\
Listeria monocytogenes ŽM58 & IHG reference strain, 4b \\
Listeria monocytogenes ŽM80 & Human isolate, 4b \\
Listeria monocytogenes ŽM92 & Isolated from chicken salad, 1/2 c \\
Listeria monocytogenes ŽM108 & Isolated from meat pasty, 4b \\
Listeria monocytogenes ŽM115 & Isolated from Tatarian beefsteak, 1/2 b \\
\hline
\end{tabular}

ŽM and ŽMJ: Culture collections of laboratory of food microbiology, Department of Food Technology, Biotechnical Faculty, Ljubljana, Slovenia; IHG: Institute for Hygiene and Microbiology, Wuerzburg, Germany

\subsection{Rosemary extracts}

We used two extracts of rosemary, VivOX 20 and VivOX 40 (Vitiva d.d., Slovenia), containing different levels of carnosic acid (VivOX 20: $22.04 \%$ and VivOX 40: $40.49 \%$ of carnosic acid)

Both extracts, VivOX 20 and VivOX 40, were prepared in absolute ethanol $(0.160 \mathrm{~g} / \mathrm{ml})$ and these $16 \%$ stock solutions were than diluted ten times till final concentration 156.25 $\mu \mathrm{g} / \mathrm{ml}$. Antibacterial effect of prepared extracts was tested on TSA (Tryptone Soy Agar, Oxoid, CM0131, England) in case of agar diffusion method and in TSB (Tryptone Soy Broth, Oxoid, CM0129, England) in case of broth dilution method.

\subsection{Determination of antimicrobial effect of rosemary extracts}

The minimum inhibitory concentrations (MICs) and minimum bactericidal concentrations (MBCs) for each extract against eleven Listeria strains were determined using a disc diffusion method and/or broth dilution method as a well-standardized and reliable reference methods that are useful for research purpose (Woods and Washington, 1999).

2.3.1 Disc diffusion method

One milliliter of overnight culture of Listeria strain was added to each plate containing TSA agar. When the agar was solidified, 4 commercially prepared filter paper discs $(6 \mathrm{~mm}$ diameter) were added on each plate. Ten microlitres of each dilution of extract was applied on each disc. The control samples were (1) $10 \mu \mathrm{l}$ of sterile distilled water as negative control and (2) $10 \mu \mathrm{l}$ of $0.01 \%$ solution of OTC (oxytetracycline, Krka, 743054, Slovenia) as positive control to control the sensitivity of the strains. After a diffusion time of $15 \mathrm{~min}$ at room temperature, the plates were incubated at 37 ${ }^{\circ} \mathrm{C}$ for $24 \mathrm{~h}$. After incubation, the inhibition zones (IZ) was measured in 2 directions and the average values were used to define MIC. The MIC was determined as lowest concentration of the rosemary extract that prevented the growth of listeria during the incubation period. Two replications of this experiment were made.

2.3.2 Broth dilution method

In this part of experiment we used two strains $L$. monocytogenes ŽM58 and L. monocytogenes ŽM115. Overnight culture was inoculated in fresh TSB medium with suitable concentration of rosemary extract. Growth of bacteria was followed at $37{ }^{\circ} \mathrm{C}$ with viable cell counts on TSA at regular time intervals for 24 and $48 \mathrm{~h}$. All data are expressed as the average of the experimental results. The MBC was determined as concentration giving $0.1 \%$ bacterial survival (Canillac and Mourey, 2003). Controls containing absolute ethanol or sterile distilled water and no extracts of rosemary were included to verify the effect of the diluent on growth of 
Listeria. Using broth dilution method four different conditions were tested:

- $\quad$ incubation of suspensions with $10 \%$ of supplements $(0.5$ $\mathrm{ml}$ culture and $0.5 \mathrm{ml}$ extract in $9 \mathrm{ml}$ sterile TSB medium) for $24 \mathrm{~h}$,

- $\quad$ incubation of suspensions with $20 \%$ of supplements (1 $\mathrm{ml}$ culture and $1 \mathrm{ml}$ extract in $8 \mathrm{ml}$ sterile TSB medium) for $24 \mathrm{~h}$,

- $\quad$ incubation of suspensions with $10 \%$ of supplements $(0.5$ $\mathrm{ml}$ culture and $0.5 \mathrm{ml}$ extract in $9 \mathrm{ml}$ sterile TSB medium) for $48 \mathrm{~h}$

- $\quad$ and incubation of suspensions with $20 \%$ of supplements (1 $\mathrm{ml}$ culture and $1 \mathrm{ml}$ extract in $8 \mathrm{ml}$ sterile TSB medium) for $48 \mathrm{~h}$.

\subsection{Statistical analysis}

For statistical analysis SAS (SAS Software. Version 8.01, 1999) was used. Data were tested for normal distribution and analyzed by the GLM (General Linear Model). For data analyses four statistical models were used:

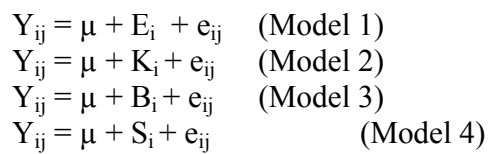

where $\mathrm{y}$ : the observation parameter, $\mu=$ general mean, $E_{i}=$ effect of extract, $\mathrm{K}_{\mathrm{i}}=$ effect of concentration of extract, $\mathrm{B}_{\mathrm{i}}=$ effect of different species of Listeria, $\mathrm{S}_{\mathrm{i}}=$ effect of different strain of $L$. monocytogenes, $\mathrm{e}=$ residual random term with variance $\sigma_{\mathrm{e}}^{2}$.

The criterion for significance in the procedure was $p<0.05$ and this indicated that data sets were significantly different between examined places. A significant difference was assigned with a different capital letter.

\section{RESULTS AND DISCUSSION}

The aim of our research was to investigate antimicrobial activity of rosemary extracts against Listeria strains and to find out MIC and MBC values with two most commonly used methods.

\subsection{Antimicrobial activity of rosemary extracts determined by disc diffusion method}

The antibacterial activity of rosemary extracts against Listeria strains which are considered in this study was assessed by evaluating the presence of IZ and MIC values. Results (Table 2), showed that the rosemary extracts have great potential of antilisterial activity against all of the eleven strains tested.

Minimal inhibitory concentration (MIC) values are expressed as $\mu \mathrm{g}$ of rosemary extract per $\mathrm{ml}$ of absolute ethanol.

The MIC values for were in the range of $625-5000$ $\mu \mathrm{g} / \mathrm{ml}$ for extract VivOX 20 and in the range of 312.5$2500 \mu \mathrm{g} / \mathrm{ml}$ for extract VivOX 40. The results of our study showed that VivOX 40 rosemary extract, which contained $40.49 \%$ of carnosic acid, had higher or the same antibacterial effect as VivOX 20, which contained

Table 2: MIC values of rosemary extracts determined with agar diffusion method

\begin{tabular}{l|ll}
\hline \multirow{2}{*}{ Listeria strain } & \multicolumn{2}{|c}{ MICs $(\mu \mathrm{g} / \mathbf{m l})$} \\
\cline { 2 - 3 } & \multicolumn{2}{|c}{ VivOX 20 } \\
L. monocytogenes ŽM51 & 2500 & 625 \\
L. monocytogenes ŽM52 & 2500 & 1250 \\
L.monocytogenes ŽM53 & 1250 & 625 \\
\hline
\end{tabular}

\begin{tabular}{l|ll}
\hline L. monocytogenes ŽM58 & 2500 & 1250 \\
L. monocytogenes ŽM80 & 2500 & 1250 \\
L. monocytogenes ŽM92 & 625 & 625 \\
L. monocytogenes ŽM108 & 2500 & 2500 \\
L. monocytogenes ŽM115 & 1250 & 312,5 \\
L. ivanovii ŽM65 & 1250 & 1250 \\
L. grayi ŽM66 & 5000 & 1250 \\
L. innocua ŽM68 & 2500 & 1250 \\
\hline
\end{tabular}

$22.04 \%$ of carnosic acid. These was in accordance with our proposal that carnosic acid was the major bioactive compound of the rosemary extract but also its derivative and other compounds like carnosol, rosmarinic acid, etc. have important antimicrobial activity. Rosemary plants are rich sources of phenolic compounds with high antioxidative and antimicrobial properties, but their antimicrobial activities have not been deeply characterized (Moreno et al., 2006). There is also some evidence that minor components have a critical part in antibacterial activity, possibly by producing a synergistic effect between other components (Burt, 2004). The absence of inhibition zone does not necessarily mean that compounds are inactive. For example, non-polar compounds may not diffuse into the culture medium (Moreno et al., 2006).

We have established with applied statistical analysis that the resistance of Listeria species against rosemary extracts depends on: selected extract, selected concentration of extract, species of Listeria and strain of L. monocytogenes (Table 3). 
Table 3: Statistical evaluation or antilisterial results obtained with disk diffusion method

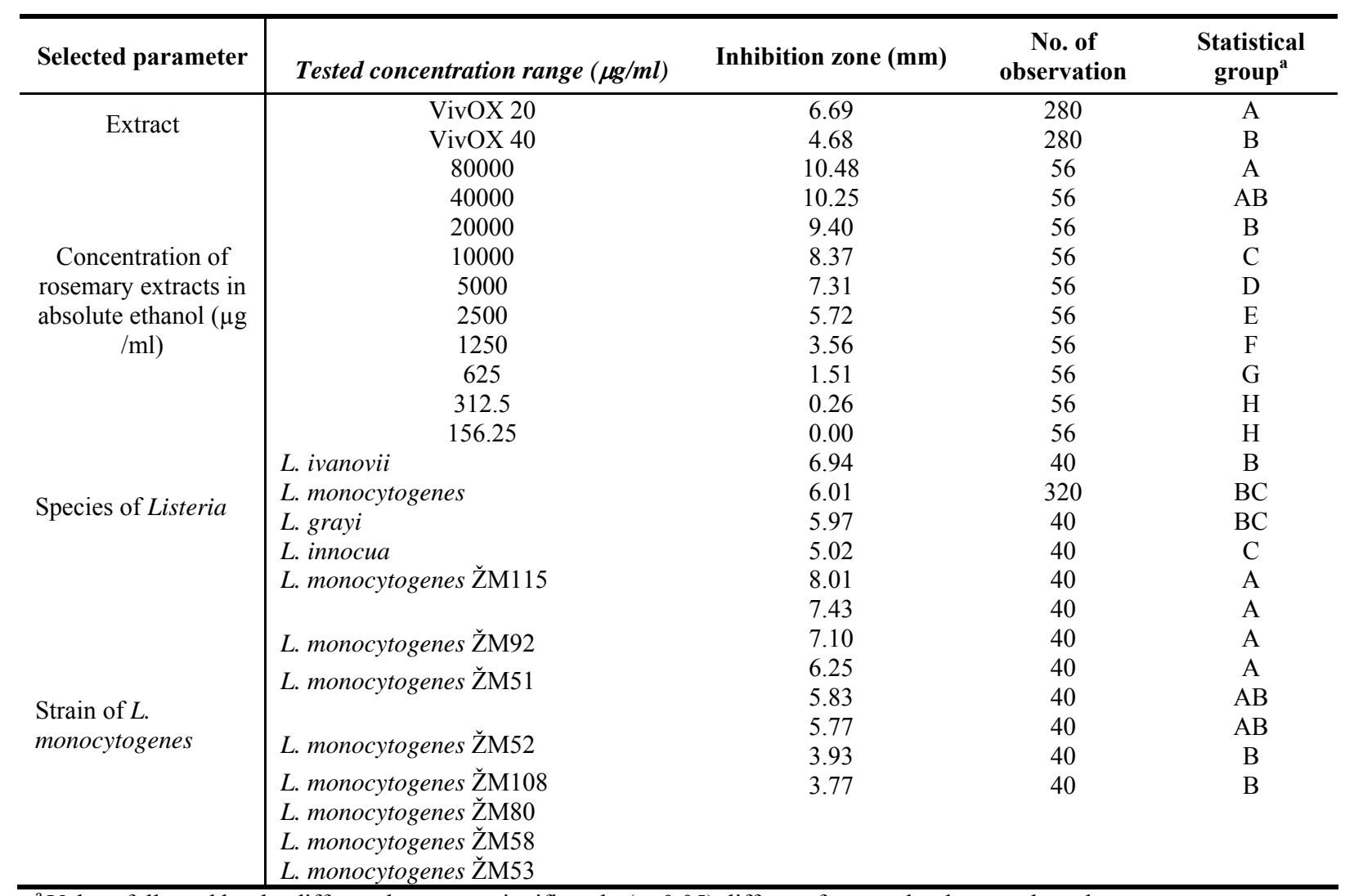

${ }^{a}$ Values followed by the different letters are significantly $(\mathrm{p}<0.05)$ different from each other at selected parameter

On the basis of results obtained with agar diffusion method, for the further experiments two strains of L. monocytogenes were selected. L. monocytogenes ŽM115 on which rosemary extracts had the highest antimicrobial effect and L. monocytogenes ŽM58 as a strain with the biggest statistical difference comparing with the first selected one (Table 3 and Figure 2).

\subsection{Antimicrobial activity of rosemary extracts determined by broth dilution method}

MBC values of rosemary extracts for L. monocytogenes ŽM58 and L. monocytogenes ŽM115 were determined by a broth dilution method.
All experiments were repeated at least two times on different days and all data are expressed as the average of the experimental results.

The MBC was read from the graph obtained by plotting the percentage of survival cells $\left(\log _{10}\right)$ versus the percentage of the corresponding concentration of rosemary extracts (Figure 2). The MBC is the concentration of rosemary extract giving $0.1 \%$ L. monocytogenes ŽM58 survival $\left(\log _{10} 0.1=-1\right)$ after $24 \mathrm{~h}$ incubation as proposed by Canillac and Mourey, 2003. 


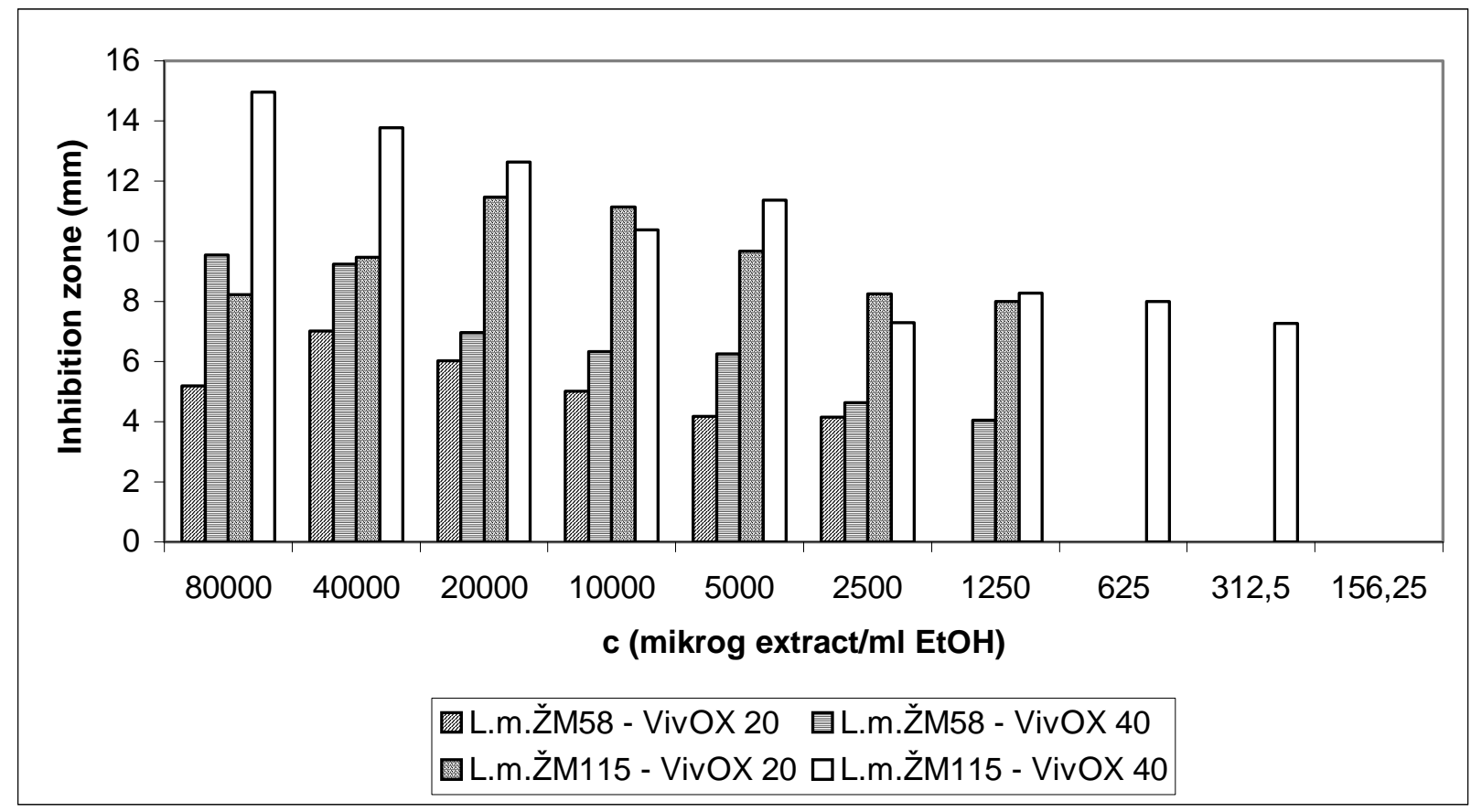

Figure 1: The average inhibition zones for L. monocytogenes ŽM58 and L. monocytogenes ŽM115 under the different concentrations of extracts VivOX 20 and VivOX 40

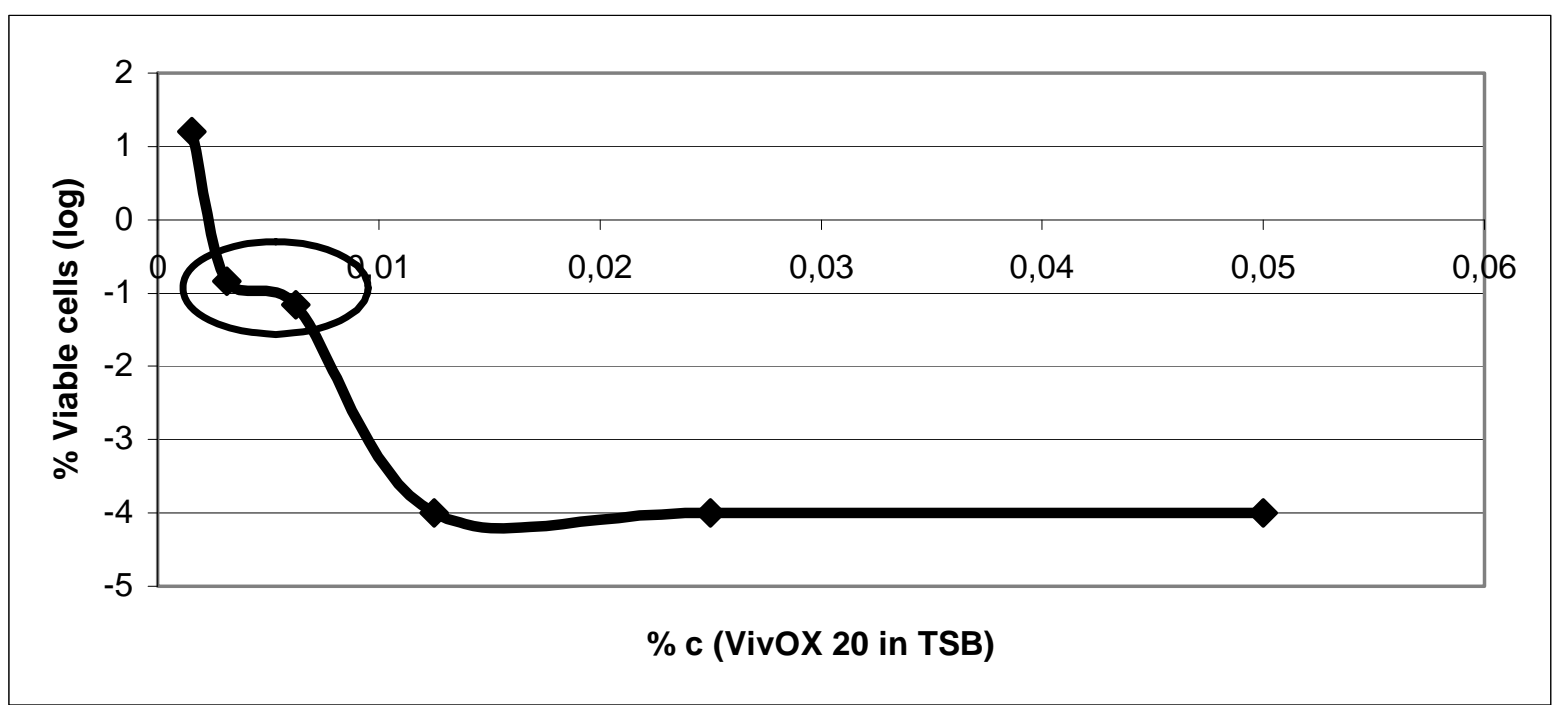

Figure 2: The effect of different concentrations of VivOX 20 on the percentage of viable cells of L. monocytogenes ŽM58 after 24 h incubation in TSB broth at $10 \%$ volume of supplement

Figure 2 shows that $\mathrm{MBC}$ is between 0 and $0.01 \%$ of rosemary extract VivOX 20 in TSB broth. For accurate results, we have calculated straight line equation and MBC $0.00539 \%$ extract in TSB broth.
In this example, the calculated $\mathrm{MBC}$ value for L. monocytogenes ŽM58 was $0.00539 \%$ of VivOX 20 in TSB broth. On the same mode all MBC values were calculated from experimental data for extract VivOX 20 and VivOX 40 under different conditions and results are summarized in table 4. 
Table 4: MBC values of VivOX 20 and VivOX 40 for L. monocytogenes ŽM115 and L. monocytogenes ŽM58

\begin{tabular}{|c|c|c|c|c|c|c|c|c|}
\hline Parameter & \multicolumn{8}{|c|}{$\operatorname{MBC}(\mu \mathrm{g} / \mathrm{ml})$} \\
\hline Type of extract & \multicolumn{4}{|c|}{ VivOX 20} & \multicolumn{4}{|c|}{ VivOX 40} \\
\hline Volume of supplement & \multicolumn{2}{|c|}{10 vol. $\%$} & \multicolumn{2}{|c|}{20 vol. $\%$} & \multicolumn{2}{|c|}{10 vol. $\%$} & \multicolumn{2}{|c|}{20 vol. $\%$} \\
\hline Incubation time & $24 \mathrm{~h}$ & $48 \mathrm{~h}$ & $24 \mathrm{~h}$ & $48 \mathrm{~h}$ & $24 \mathrm{~h}$ & $48 \mathrm{~h}$ & $24 \mathrm{~h}$ & $48 \mathrm{~h}$ \\
\hline L. monocytogenes ŽM115 & 401.0 & 252.5 & 15.63 & 40.7 & / & / & $<31.25$ & / \\
\hline L. monocytogenes ŽM58 & 53.9 & 98.5 & / & / & 42.4 & 56.0 & / & / \\
\hline
\end{tabular}

MBC: Minimal bactericidal concentration value is expressed as $\mu \mathrm{g}$ of rosemary extract per ml of TSB broth; /: not done

MBC values recorded for both rosemary extracts were often greater after 48 than $24 \mathrm{~h}$ incubation (Table 4). VivOX 20 extract was effective against L. monocytogenes ŽM115 with an MBC $401 \mu \mathrm{g} / \mathrm{ml}$ after $24 \mathrm{~h}$ incubation and $252.5 \mu \mathrm{g} / \mathrm{ml}$ after $48 \mathrm{~h}$ incubation, with $10 \%$ of supplements. In contrast, with $20 \%$ of supplements and the same strain of Listeria, MBC was $15.63 \mu \mathrm{g} / \mathrm{ml}$ after $24 \mathrm{~h}$ and $40.7 \mu \mathrm{g} / \mathrm{ml}$ after $48 \mathrm{~h}$ incubation. When $31.25 \mu \mathrm{g} / \mathrm{ml}$ of VivOX 40 extract was used, a $99.9 \%$ inhibition was observed after $24 \mathrm{~h}$. A higher bactericidal effect was found testing extract VivOX 20 with L. monocytogenes ŽM58, because 53.9 $\mu \mathrm{g} / \mathrm{ml}$ were necessary to obtain MBC after $24 \mathrm{~h}$ and $98.5 \mu \mathrm{g} / \mathrm{ml}$ after $48 \mathrm{~h}$ incubation with $10 \%$ addition of supplements. VivOX 40 showed similar MBC values against L. monocytogenes ŽM58 with also $10 \%$ of supplements: $42.4 \mu \mathrm{g} / \mathrm{ml}$ after $24 \mathrm{~h}$ and $56.0 \mu \mathrm{g} / \mathrm{ml}$ after $48 \mathrm{~h}$ incubation. The strain of $L$. monocytogenes ŽM115 was slightly less sensitive. We assumed that this strain, isolated from Tatarian beefsteak was exposed to different stress conditions (change in $\mathrm{T}, \mathrm{pH}$, etc.) and this consecutively lead to increase strain's resistance. The results also shows that bigger quantity of supplements in TSB broth decrease MBC, that is why we assumed that this lead to changes the composition of broth.

\section{CONCLUSIONS}

Here, we describe the antimicrobial activity of rosemary extracts against Listeria strains. Our results show that both extracts VivOX 20 and VivOX 40 had a good antimicrobial activity against several strains of Listeria. The definition of the MIC and MBC differs between publications and this is obstacle to comparison results between studies. More effective was extract VivOX 40, which contained a higher percent of carnosic acid, but the differences in MIC and MBC between the extracts were not so high, so we assumed that also other compounds in extracts had important antimicrobial activity. We confirmed that antimicrobial activity of rosemary extracts was dependent on selected rosemary extract, concentration of extracts, different species of Listeria and different strains of $L$. monocytogenes.

\section{ACKNOWLEDGEMNT}

The authors gratefully acknowledge Vitiva d.d., Slovenia for providing rosemary extracts VivOX 20 and VivOX 40.

\section{REFERENCES}

Burt S. 2004. Essential oils: their antibacterial properties and potential applications in food - a review. International Journal of Food Microbiology, 94: 223-253

Carrasco E., Valero A., Perez-Rodriguez F., Garcia-Gimeno R.M., Zurera G. 2006. Management of microbiological modelling: Listeria monocytogenes as an example. International Journal of Food Microbiology, 114: 221226

Cannilac N., Mourey A. 2001. Antibacterial activity of the essential oil of Picea excelsa on Listeria, Staphylococcus aureus and coliform bacteria. Food Microbiology, 18: 261-268

Del Campo J., Amiot M.J., Nguyen-The C. 2000. Antimicrobial effect of rosemary extracts. Journal of Food Protection, 10: 1359-1368 
Duxbury D. 2004. Keeping tabs on Listeria. Food Technology, 58: 74-80

Fenlon D.R. 1999. Listeria in the natural environment. V: Listeria, listeriosis and food safety. $2^{\text {nd }}$ ed. Ryser E.T., Marth E.H. (ur.). New York, Marcel Dekker, Inc.: 21-38

Fernandez-Lopez J., Zhi N., Aleson-Carbonell L., PerezAlvarez J.A., Kuri V. 2004. Antioxidant and antibacterial activities of natural extracts: application in beef meatballs. Meat Science, 69: 371-380

Gandhi M., Chikindas M.L. 2007. Listeria: A foodborne pathogen that knows how to survive. International Journal of Food Microbiology, 113: 1-15

Lado B.H., Yousef A.E. 2007. Characteristic of Listeria monocytogenes important to food procesors. In: Listeria, listeriosis and food safety. $3^{\text {rd }}$ ed. Ryser E.T., Marth E.H. (eds.). New York, CRC Press, Taylor \& Francis Group, Inc.: $157-214$

Lo A.H., Liang Y.C., Lin-Shiau S.Y., Ho C.T., Lin J.K. 2002. Carnosol, an antioxidant in rosemary, suppresses inducible nitric oxide synthase through down-regulating nuclear factor $-\kappa \mathrm{B}$ in mouse macrophages. Carcinogenesis, 23: 983-991

Lopez-Malo Vigil A., Palou E., Alzamora S.M. 2005. Naturally occurring compounds-plant sources. In: Antimicrobials in food. $3^{\text {rd }}$ ed. Davidson P.M., Sofos J.N., Branen A.L. (eds.). Boca Raton, Taylor \& Francis Group: 429-451

Manzano M., Cocolin L., Ferroni P., Cantoni C., Comi G. 1997. A simple and fast PCR protocol to detect Listeria nonocytogenes from meat. Journal of the Science of Food and Agriculture, 74: 25-30

Moreno S., Scheyer T., Romano C.S., Vojnov A.A. 2006. Antioxidant and antimicrobial activities of rosemary extracts linked to their polyphenol composition. Free Radical Research, 40: 223-231

Nychas G.J.E. 1995. Natural antimicrobials from plants. In: New methods of food preservation. Gould G.W. (ed.). London, Blackie Academic and Professional: 58-89

Ouattara B., Simard R.E., Holley R.A., Piette G.J.-P., Begin A. 1997. Antibacterial activity of selected fatty acids and essential oils against six meat spoilage organisms. International Journal of Food Microbiology, 37: 155-162

Painter J., Slutsker L. 2007. Listeriosis in humans. In: Listeria, listeriosis and food safety. $3^{\text {rd }}$ ed. Ryser E.T., Marth E.H. (eds.). New York, CRC Press, Taylor \& Francis Group, Inc.: $85-110$

Rocourt J., Buchrieser C. 2007. The genus Listeria and Listeria monocytogenes: phylogenetic position, taxonomy, and identification. In: Listeria, listeriosis and food safety. $3^{\text {rd }}$ ed. Ryser E.T., Marth E.H. (eds.). New York, CRC Press, Taylor \& Francis Group, Inc.: 1-20

Shelef L.A. 1983. Antimicrobial effects of species. Journal of Food Safety, 6: 29-44

Vazquez-Boland J., Dominguez-Bernal G., Gonzalez-Zorn B., Kreft J., Goebel W. 2001. Pathogenical islands and virulence evolution in Listeria. Microbes and Infection, 3: $571-584$

Woods G.L., Washington J.A. 1999. Antimicrobial susceptibility tests: dilution and disk diffusion methods. In: Manual of clinical microbiology. Murrey P.R., Baron E.J., Pfaler M.A., Tenover F.C., Yolken R.H. (eds.). Washington, American Society for Microbiology: 13271341

Zhang Y., Yeh E., Hall G., Cripe J., Bhagwat A.A., Meng J. 2007. Characterization of Listeria monocytogenes isolated from retail foods. International Journal of Food Microbiology, 113: 47-53 